\title{
A Report from the
} International Database on Energy Efficiency Programs (INDEEP) Project

\section{INTERNATIONAL DSM AND DSM PROGRAM EVALUATION: AN INDEEP ASSESSMENT}

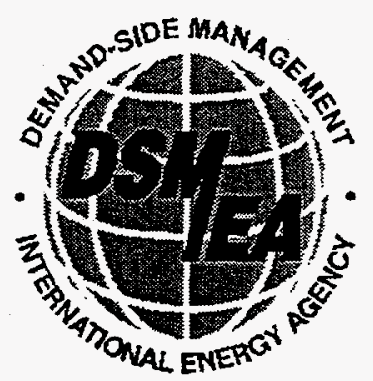

\section{Edward Vine}

Energy Analysis Program, Energy and Environment Division

Lawrence Berkeley Laboratory, Building 90-4000

University of California, Berkeley, CA 94720 USA

\section{April 1995}

Presented at the 1995 Summer Study of the European Council for an Energy-Efficient Economy,

Mandelieu, France, June 6-10, 1995

This work was supported by the Assistant Secretary for Energy Efficiency and Renewable Energy, Office of Utility Technologies, of the U.S. Department of Energy under Contract No. DE-AC0376SF0098; Energieverwertungsagentur (Austria); DEFU (Denmark); Commission of the European Union (Joint Research Center); RaCER (Korea); NOVEM (Netherlands); Red Electrica de España and UNESA (Spain); and NUTEK (Sweden). 


\section{DISCLAIMER}

Portions of this document may be illegible in electronic image products. Images are produced from the best available original document. 
International DSM and DSM Program Evaluation: An INDEEP Assessment

Edward Vine

Energy Analysis Program

Energy and Environment Division

Lawrence Berkeley Laboratory

\begin{abstract}
This paper discusses the current level of demand-side management (DSM) occurring in selected European countries and reviews the availability of information on DSM programs and program evaluation. Next, thirteen European DSM programs are compared by examining such factors as: motivations for program implementation, marketing methods, participation rates, total energy savings, and program costs. The transfer of DSM program results and experiences found in these case studies is also discussed, as well as the lessons learned during the design, implementation, and evaluation of these programs.
\end{abstract}

This paper represents a preliminary assessment of the state of DSM and DSM program evaluation in Europe. The findings from this work also represent the first steps in a joint international effort to compile and analyze the measured results of energy efficiency programs in a consistent and comprehensive fashion. We find that these programs represent cost-effective resources: the cost of energy saved by the programs ranged from a low of $0.0005 \mathrm{ECUs} / \mathrm{kWh}(0.01 \phi / \mathrm{kWh})$ to a high of $0.077 \mathrm{ECUs} / \mathrm{kWh}(9.7 \phi / \mathrm{kWh})$, with an average cost of $0.027 \mathrm{ECUs} / \mathrm{kWh}(3.3 \phi / \mathrm{kWh})$. Weighted by energy savings, the average cost of energy saved by the programs was $0.014 \mathrm{ECUs} / \mathrm{kWh}(1.8 \mathrm{c} / \mathrm{kWh})$. We expect that these types of DSM programs will be useful for utilities and governments in the future for both energy and non-energy reasons. 


\section{INTRODUCTION}

Demand-side management (DSM) is at a critical juncture in both Europe and the United States. ${ }^{1}$ Facing a more competitive future with possible restructuring (in organization, ownership, and regulation) of the power industry and the availability of lower cost power (purchased or generated), utilities in Europe and the United States are questioning the value and role of DSM. The reality and perception of increasing price competition, in particular, is leading some utilities to reduce or eliminate their DSM programs because these programs may increase electricity prices (Hirst and Hadley 1994). However, the benefits of DSM will likely continue to be an important focus for utilities wanting to offer high quality service to their customers (in order to retain and enhance their customer base), as well as for energy efficiency and environmental reasons. The evaluation of DSM programs is critical, and program evaluation is expected to become even more important in the near future as the performance and value of DSM programs are closely scrutinized in a more competitive environment. However, the traditional use of program evaluation for assessing the cost and performance of DSM programs may change in the future as DSM programs and evaluation needs adapt to a more competitive (market-based) utility environment.

The purpose of this paper is to examine the experience of European utilities and governments in DSM programs and program evaluation. The findings are the first results from a joint international effort in compiling and analyzing the measured results of energy efficiency programs in a consistent and comprehensive fashion (the INDEEP project, see below). Where available, the program results are based on post-program evaluations rather than on unverified program estimates. While the countries and case studies examined are not representative of all of Europe, they are valuable for illustrating the types of DSM programs and the level of program evaluation occurring in Europe today.

This paper includes a brief overview of the International Database on Energy Efficiency Programs (INDEEP) project, DSM and DSM program evaluation in Europe, and the 13 DSM programs analyzed, as well as discussions of the total cost and performance of the 13 programs, lessons learned from these programs, and general conclusions regarding the transfer of DSM program experience and the future of DSM and DSM program evaluation in Europe.

\section{IEA DSM Agreement and the INDEEP Project}

The International Energy Agency (IEA) Demand-Side Management Implementing Agreement is an international collaboration with 14 IEA member countries, plus Korea and the European Union, working to clarify and promote opportunities for DSM. The Agreement has 5 Tasks (the term Task is used to describe the work to be done under the contractual Annex to the Agreement). The objective of Task 1 is to 
establish an international data base on DSM, analyze the data collected, and disseminate the information which results from the analysis (Vine 1993). The International Database on Energy Efficiency Programs (INDEEP) project will make available information on electric and gas utility DSM programs as well as those carried out by others (e.g., government agencies and energy service companies). Initially, the data base will consist of programs implemented by the seven countries participating in this Task (Austria, Denmark, Korea, Netherlands, Spain, Sweden, and the United States). ${ }^{2}$ This paper is based on work conducted during the first year of the INDEEP project.

\section{OVERVIEW OF DSM AND DSM PROGRAM EVALUATION}

In many European countries, governments and utilities are involved in the design, implementation, and evaluation of energy efficiency and DSM programs. For example, since the early 1970s, governmental agencies have promoted energy efficiency building codes and standards in the residential sector. Interest in appliance and equipment efficiency standards is also becoming more widespread, although many countries are waiting to see how the Commission of the European Union's directive on standards for freezers and refrigerators, and its directive on labeling for dishwashers, washing machines, and dryers will be implemented.

European utilities have promoted DSM for many years, primarily through time-of-use rates (for sending the appropriate price signals to their customers) (CIGRE 1994). An analysis of European DSM activities found that the most frequently used DSM strategies currently being implemented in Europe are time-of-day rates and information campaigns (used in all surveyed countries), followed by research and development, seasonal rates, energy audits, and labeling of appliances (UNIPEDE 1994). Thus, until recently, most European DSM programs have been load management programs (targeting reductions in energy demand $(\mathrm{kW})$ ) rather than energy efficiency programs (targeting reductions in energy use (kWh)). Most DSM programs focus on the residential sector and cover the following end uses: electric water heating, electric space heating, and residential lighting. ${ }^{3}$ The commercial sector applications are mainly for lighting, heating, and air conditioning. And in the industrial sector, lighting is the main targeted end use, followed by cogeneration, heating, ventilation, and air conditioning (HVAC), interruptible loads, and efficient motors.

Program evaluation in Europe is in its infancy, although, as noted below, some countries are becoming more experienced in this field. The UNIPEDE survey mentioned above found that about $50 \%$ of DSM programs are evaluated by using only program tracking database estimates; $30 \%$ are evaluated by two methods (tracking database estimates and measured consumption (billing analysis or end-use metering)); and $10 \%$ by tracking database estimates, billing analysis, and end-use metering (the remaining $10 \%$ did not answer the survey question). 
In the INDEEP project, each participant reviewed their country's experience in the following areas: (1) existing and future DSM program data bases; (2) existing and future DSM data collection activities; (3) methods used (or planned) to evaluate DSM programs; and (4) available evaluation technical assistance. Highlights of this experience are summarized in Table 1, and a more detailed description on some of these areas is found below. In general, most participating countries in Europe have not developed a comprehensive data base on DSM programs and evaluation results; most of the existing data bases focus on technologies (rather than programs). All of the European participants expect the INDEEP data base to serve as the repository for information on their DSM programs. The types of DSM data collected in these European countries are varied, ranging from market sales data on specific equipment to monitoring data of government and utility programs. Finally, the experience of DSM program evaluation is relatively recent and limited, when compared to the efforts undertaken in the United States. Some governments have developed their own evaluation and monitoring guidelines and handbooks (e.g., Netherlands and Sweden). And the DSM projects funded by the Commission of the European Union (under the SAVE program) offer the possibility of providing more evaluation tools for evaluators in Europe. ${ }^{4}$

The rest of this section provides a more detailed overview of DSM, DSM data collection activities, and the status of DSM program evaluation activities in each country participating in the INDEEP project.

\section{Austria}

Austria has been involved in load management and information (including energy audits) projects for a number of years, but has only recently started implementing more diverse DSM programs. ${ }^{5}$ While the Länder (provinces or regional governments) are responsible for building codes, the regional utilities are the primary DSM program delivery agents. The most common DSM technologies being implemented involve providing energy services, appliance efficiency, and appliance control. The most common DSM programs offer information, education, and rebates, targeted towards residential and commercial customers.

Currently, Austria does not collect data on DSM programs. In a recent survey of Austrian utilities, $40 \%$ reported that they had never evaluated their programs, and only one DSM program had been evaluated using the methodologies developed in the U.S. (Schmid 1993). The Austrian Association of Power Utilities is participating in a SAVE project with the German Association of Power Utilities, and evaluation guidelines may be included in the project's guidebook for Least-Cost Planning. 
Table 1. Overview of DSM Program Experience

\begin{tabular}{|c|c|c|c|}
\hline Country & DSM Data Bases & DSM Data Collection Activities & DSM Program Evaluation Experience \\
\hline Austria & None. & None. & $\begin{array}{l}\text { (1) } 60 \% \text { of Austrian utilities evaluate their } \\
\text { programs. } \\
\text { (2) Evaluation guidelines may be included in a } \\
\text { SAVE-project guidebook. }\end{array}$ \\
\hline Denmark & $\begin{array}{l}\text { (1) Residential appliance data base. } \\
\text { (2) Energy consulting service data base for } \\
\text { industry \& tertiary sector. }\end{array}$ & $\begin{array}{l}\text { (1) Energy consulting service data in industry } \\
\text { \& tertiary sector. } \\
\text { (2) Load research data for all large consumers, } \\
\text { and for representative panels in main } \\
\text { sectors (residential, commercial, } \\
\text { industrial, and agricultural). } \\
\text { (3) Time-of-day tariff data for all sectors. }\end{array}$ & $\begin{array}{l}\text { (1) Extensive evaluation experience by utilities } \\
\text { and distribution companies. } \\
\text { (2) Methods for evaluating DSM and supply- } \\
\text { side options being developed in a SAVE } \\
\text { project. }\end{array}$ \\
\hline $\begin{array}{l}\text { Commission } \\
\text { of the } \\
\text { European } \\
\text { Union }\end{array}$ & None. & $\begin{array}{l}\text { EU-funded SAVE program data may be } \\
\text { collected. }\end{array}$ & $\begin{array}{l}\text { Unclear on extent of evaluation of SAVE } \\
\text { programs. }\end{array}$ \\
\hline Netherlands & Technology data base. & $\begin{array}{l}\text { (1) Government and utlity program } \\
\text { monitoring; data. } \\
\text { (2) Data on government and university } \\
\text { demonstration and R\&D projects, and } \\
\text { subsidy programs. }\end{array}$ & $\begin{array}{l}\text { (1) Extensive evaluations conducted by } \\
\text { distribution companies and their branch } \\
\text { organizations, and by government. } \\
\text { (2) Program monitoring system and handbook } \\
\text { developed by government. }\end{array}$ \\
\hline Spain & $\begin{array}{l}\text { Appliance and building consumption data base } \\
\text { for all sectors. }\end{array}$ & $\begin{array}{l}\text { Appliance and building consumption data for a } \\
\text { sample of customers from different sectors. }\end{array}$ & Very little. \\
\hline Sweden & $\begin{array}{l}\text { Program and audit data base for commercial } \\
\text { sector. }\end{array}$ & Equipment sales data. & $\begin{array}{l}\text { (1) All governmental programs evaluated; } \\
\text { utility evaluations done but most are } \\
\text { confidential. } \\
\text { (2) Government has its own evaluation } \\
\text { planning process. }\end{array}$ \\
\hline United States & $\begin{array}{l}\text { Many program and technology data bases (see } \\
\text { Vine et al. 1993). }\end{array}$ & $\begin{array}{l}\text { Extensive data collection efforts by } \\
\text { government and industry organizations (see } \\
\text { Vine et al. 1993). }\end{array}$ & $\begin{array}{l}\text { (1) Extensive evaluation experience by utilities } \\
\text { and government. } \\
\text { (2) Evaluation guidelines and protocols } \\
\text { developed for some states. } \\
\text { (3) Large consulting industry in evaluation. }\end{array}$ \\
\hline
\end{tabular}




\section{Denmark}

The Danish government promotes energy efficiency through regulations, standards, and labeling for buildings and appliances. Other activities include energy consultancy (auditing) schemes, energy management in buildings, energy efficiency financing arrangements, programs for public buildings and for the conversion of electricity-heated buildings to district heating or natural gas, and voluntary agreements with industry. The most common DSM measures involve lighting, appliance efficiency, and energy audits (commercial and industrial).

The electric utilities are very active as DSM delivery agents, and they recently completed a study on integrated resource planning. They have a long tradition in providing advice on the rational use of energy in the domestic sector. The customers are free to contact their utility and receive guidance on the purchase and use of household appliances. A data base containing 75,000 items of information about 1,500 different types of applications is available.

Since 1987, an energy consultancy service for industry and the tertiary sector has been established as a key DSM activity. Results from nearly all cases where customers have used the energy consultancy service have been collected in a data base called ENIBASE (developed by DEFU, a research association of the Danish electric utilities). This data base includes information, such as: yearly consumption for 12 end uses, proposed and actual savings by end use, and investment and simple payback times for each proposed savings project. By the end of 1994, ENIBASE contained 3,500 completed cases.

A comprehensive research project is being established to collect load data for all large consumers (annual consumption exceeding $10 \mathrm{GWh}$ ), representative panels for the main consumer categories (residential, commercial, industrial, and agricultural), and some consumer categories as well as end-use applications. The purpose of this project is to observe changes in energy consumption and, to some extent, verify major DSM activities.

During the last eight years, all Danish utilities have started to use a time-of-day tariff with three price levels during the day. Energy use can be analyzed for a single customer, a consumer category, a tariff group, or all customers in the system. Each year, these data are collected from the utilities in order to analyze the impact of time-of-day tariffs on consumption.

Until now, the type of data used to evaluate DSM activities has varied from case to case: (1) market research data on the penetration of energy-efficient appliances, (2) sales statistics to determine the level of sales of energy-efficient appliances, (3) survey data on the use of appliances, (4) customer 
billing data, (5) data on financing of DSM activities, (6) ENIBASE data, (7) load research data, and (8) time-of-day data. Recently, the Danish Electric Utilities completed a SAVE project to develop methods for assessing demand-side (and supply-side) activities.

\section{Netherlands}

Since 1990, DSM and energy efficiency programs have been promoted under an environmental task. In that year, the Dutch government published the National Environmental Policy Plan and Memorandum on Energy Conservation. At the same time, the Dutch energy distribution sector assumed their own responsibility for improving energy efficiency and reducing $\mathrm{CO}_{2}$ emissions, and their DSM programs are based on national agreements with the Ministry of Economic Affairs: the Environmental Action Programs of 1991 and 1994. The most common DSM measures involve lighting, boilers, building management, residential insulation, and combined heat and power. The most common types of DSM programs target lighting, district heating, and general operations and maintenance.

The Ministry of Economic Affairs has signed voluntary agreements with industries, and discussions are being held with small enterprises, commercial services, and the retail, education, health, and agriculture sectors. Sixteen long-term agreements have been negotiated with industrial subsectors representing about $80 \%$ of total Dutch industrial energy demand. The agreements are generally negotiated with industrial associations and are binding on individual member firms. The parties commit to reduce energy use by a specified percentage by 2000 relative to 1989; typical commitments are of the order of $20 \%$. In exchange, the firms receive technical support from NOVEM (a government energy agency).

The Government is also developing appliance and building standards for limiting energy consumption in heating, cooling, and lighting. The appliance standards are being developed in coordination with other countries and the Commission of the European Union. For building standards, the Energy Performance Standard restricts total heating use in a building and requires specific levels of insulation.

Three utility organizations are involved in DSM activities and the reporting of DSM program results: (1) EnergieNed (a branch organization of distribution companies) monitors and reports on the yearly progress of the National Environmental Action Program at the national level and conducts evaluations (the distribution companies also report and evaluate their actions); (2) GasUnie (the national gas production company) conducts and evaluates efficiency programs targeted to large industry; and (3) SEP (the electricity generating board) is involved in DSM activities and the modeling of electricity demand and has recently completed a study on integrated resource planning. Gastec (a natural gas research 
institute) and KEMA (an independent service organization, jointly owned by electricity producers and distributors) are involved in the development of energy efficiency technology and tools. Presently, most of the information collected by these organizations is not distributed commercially, or the distribution is limited to program summaries.

NOVEM publishes program summaries and the results of demonstration projects and research and development (R\&D) activities on a regular basis, as well as information on energy applications and energy efficiency potentials. A data base on university R\&D programs is available on-line. Subsidy programs are published in official government publications and on-line data bases.

EnergieNed has developed a system for reporting the activities of the energy distribution companies and their progress in the achieving selected energy and environmental goals. The collection of data is done very systematically, using instruction leaflets, and supported by a handbook. EnergieNed evaluates some actions of distribution companies at the national level. But most DSM projects are managed by distribution companies that use their own evaluation design, depending on company standards. No general approach to evaluation has emerged.

Recently, the Ministry of Economic Affairs developed a monitoring system to track the activities of energy distribution companies, as well as other organizations involved in the management of energy programs (e.g., NOVEM). A handbook (catalogue) on these activities is being prepared. In addition, NOVEM has been developing an internal system and guidebook for monitoring its own programs, compatible with the Ministry of Economic Affairs' system. Generally, all programs are evaluated regularly (every 3 to 5 years), and reports are available.

\section{Spain}

Spain's experience in DSM is relatively recent. The most common DSM strategies are time-of-day tariffs and interruptible supply contracts for customers with annual loads greater than $5 \mathrm{MW}$. The most common DSM technologies involve water heating, space heating, and load control.

The National Energy Plan 1991-2000 (adopted by the Parliament in 1992) has established an energy savings program under the Energy Conservation and Efficiency Plan which may lead to more energysaving projects in the near future. A pilot project to estimate the potential improvements in electricity end-use efficiency started in 1994. This project is principally designed to advise customers in the tertiary (service) sector about lighting efficiency improvements. 
The NOE data base contains information collected through the INDEL and EFIRE Projects. The INDEL Project is a study of country-wide electric power demand which has been going on since 1988. This project tries to model the evolution of demand over time and determine the most significant external factors affecting customers' load changes and daily demand profiles. The project data are obtained from intensive examination of consumption and daily load curves in all sectors. In an associated project in the residential sector, the EFIRE Project seeks to develop a model to evaluate the impact of DSM measures on household appliance usage in the residential sector. Energy consumption of major appliances is monitored in a sample of homes.

Spain is also developing a technical/economic model, MINDRE, to evaluate the impact of DSM programs on the efficient use of electric power generating equipment for low-voltage consumers, and night tariffs on energy usage by residential customers.

\section{Sweden}

For many years, Sweden has been involved in promoting energy efficiency in all sectors. Since 1991, the Swedish National Board for Industrial and Technical Development (NUTEK) has encouraged energy efficiency through procurement of energy-efficient technology, demonstration projects in residential and commercial premises, industrial demonstrations and pilot installations, and information and advice to small and medium-sized industries. As an example of the first activity, NUTEK encouraged manufacturers to make available more energy-efficient refrigerators through a co-operative government-organized purchase, which resulted in new refrigerators that were $35 \%$ more efficient than the market average (NUTEK 1993). NUTEK continues to introduce programs to encourage the development of new energy-efficient technologies, such as: low U-value window, high-frequency lighting, auto-power-down monitors, efficient ventilation systems for retrofits, and efficient washing machines and dryers. The National Board for Housing, Building, and Physical Planning is responsible for the Swedish building code that has played a significant role in Sweden's energy efficiency efforts.

NUTEK has a DSM program data base and an audit data base on the commercial sector from STIL (statistical studies in commercial buildings), one of the activities sponsored by Vattenfall Uppdrag 2000. The data are based on energy audits of a sample of commercial customers for 1991.

All NUTEK activities (including joint/coordinated utility activities) are evaluated. DSM programs run by utilities at their own cost might be evaluated by the utilities, but, due to uncertainty about the deregulated market, most utilities plan to keep their evaluations confidential. NUTEK and associated utility programs are evaluated using the evaluation planning process developed by NUTEK and the 
methods developed in the U.S. (Bowie 1993). For market transformation programs, NUTEK is examining trend shifts in equipment purchases (e.g., refrigerators or high frequency ballasts) and trying to determine how much of the shift in trends is due to the market transformation program.

\section{DSM PROGRAM CASE STUDIES}

The 13 case studies examined in this paper were selected by the INDEEP experts for field testing the data collection instrument prepared for the INDEEP project, and the programs reflect a diverse sample covering several sectors and different load shape objectives. The case studies may represent a biased sample since it is likely that the most "successful" programs were chosen for this study. The number of case studies per country reflects to a certain degree the amount of DSM activity within each country (as described in the previous section). Finally, the case studies include results from program evaluations, although, in some cases, energy savings may be based more on engineering estimates rather than measured data (e.g., billing or end-use metered data). Prior to comparing selected program components (Tables 2-4), we briefly describe each program.

\section{Austria: District Heating and Fuel Switching Program}

Since 1992, the municipal utility of Salzburg (Salzburger Stadtwerke AG) has offered a service package to contractors and heating system operation authorities to promote the use of district heating or the conversion of fuels from oil and coal to gas. The service package provides control engineering and hydraulic optimization services and a 24-hour repair service. The program is targeted to multi-family housing (existing and new) that uses oil or coal-based energy. To reduce the barrier of high investment costs, service connection costs were calculated as if all multifamily occupants were participating (even if not all were willing to switch to district heating or gas).

\section{Austria: Electric Appliance Exchange Program}

In 1989, the Austrian utility SAFE (Salzburger AG für Energiewirtschaft) launched a rebate program for the exchange of electric household appliances (Haas 1995). The objective of the program was to replace as many inefficient household appliances as possible in the Austrian federal state of Salisbury, in order to save energy and to examine how much energy efficiency could contribute to future electricity supply security. The program consisted of two major elements: a rebate for investments and a bounty (reward) for conserved energy $(\mathrm{kWh}$ ). The rebate was either $20 \%$ of the initial electricity bill or $20 \%$ of the price of the new appliance. Each participant got a rebate for only one appliance. The rebate was subject to the condition that the old unit was given to SAFE for disposing the appliance to a licensed 
local recycling company. The bounty was an additional amount of half the electricity price for each $\mathrm{kWh}$ saved, up to a maximum of $5 \%$ of the initial electricity bill, for three years following the program.

\section{Austria: Heat Pump Program}

In 1980, Upper Austria's Provincial Government and the Upper Austrian Electric Power Company Ltd. (OKA) implemented a program to promote the use of heat pumps to further the goal of fuel switching from fossil fuels to electricity in the residential sector. The program targets people living in one- to three-family houses with certain income limits. In addition to homeowners, the program targets manufacturers of heat pumps, plumbers, and retailers. The program is marketed through newspaper advertising, newsletters, seminars and workshops, and rebates (370 ECU (\$440) for heat pumps for water heating, and 1,480 ECU $(\$ 168)$ or $2,220 \mathrm{ECU}(\$ 2,664)$ for heat pumps for space heating (depending on the chosen technology)). ${ }^{6}$

\section{Austria: Commercial Load Management Program}

In 1992, the Vienna utility Wiener Stadtwerke Wienstrom launched a pilot load management program for commercial customers. Since September 1994, the program has been operating as a full-scale program to all commercial customers. The primary load management objectives are peak clipping and load shifting. In addition to organizing seminars for trade allies to inform them about load management, the utility also offered to install a load management system that meets the customer's needs.

\section{Denmark: Low-Energy Freezers Program}

In 1993, a Danish electric utility promoted low-energy freezers in the residential market. In addition to media advertising (newspapers, radio, and television), the utility offered rebates to homeowners for replacing existing freezers with energy-efficient freezers. The utility was responsible for making sure that the old appliances were properly disposed. At the end of 1994, a national campaign was created to promote low-energy freezers.

\section{Denmark: Industrial Audit Program}

ELSAM (one of two power pools in Denmark and jointly owned by six generating companies) reported on how Danish electric utilities offer free audits to industrial customers. Since 1987, the program has targeted industrial customers with electricity consumption above $200,000 \mathrm{kWh}$ per year. All of these 
customers (1700) have been contacted, $90 \%$ have received an audit, and $30 \%$ of the audited customers have implemented some of the recommended measures.

\section{Denmark: Trade and Public Sector Audit Program}

The third Danish program is the national program of free audits to the public sector. The program targets customers with electricity consumption above 200,000 kWh per year. All of these customers (3700) have been contacted, $95 \%$ have received an audit, and $30 \%$ of the audited customers have implemented some of the recommended measures.

\section{Denmark: Residential Lighting Program}

The utilities in Denmark have conducted several programs to promote efficient lighting in the residential sector. ELSAM reported on a national program in 1993 which relied on newspaper, radio, and television advertisements to encourage people to use compact fluorescent lamps (CFLs). Now, the total sale in Denmark of compact fluorescent lamps is the same as the number of people in Denmark: 5 million CFLs, or 2.2 CFLs per home on average.

\section{Netherlands: Compact Fluorescent Lamp Program}

Between Sept. 1993 and Feb. 1994, the Dutch energy distribution companies implemented a national campaign to promote the use of CFLs. The energy distribution companies were assisted by EnergieNed, CFL manufacturers, and the Ministry of Economic Affairs. The mass media (e.g., radio and television) was used extensively to advertise the program. In addition, a lottery with prizes was offered to those who submitted bar codes from the CFLs on special coupons. A television show (Voila's Voltshow) had energy-saving quizzes and announced the lottery winners. The special coupons were distributed door-todoor and inserted in the utility magazine (Energy and Water). During the national campaign, 2.9 million CFLs were sold and the numbers of households with at least one CFL increased from $49 \%$ to $56 \%$. Most of the participants in the program bought an average of 2 CFLs per household.

\section{Netherlands: Energy Efficient Refrigerator and Freezer Program}

This program promotes "green" refrigerators and freezers: these appliances are energy efficient and meet certain environmental conditions, as discussed below. Customers who buy an energy-efficient refrigerator or freezer receive a $23 \mathrm{ECU}(\$ 28)$ discount from the retailer who can then apply for a rebate at the participating utility. The price discount is only offered for appliances on a "green list" that 
shows CFC-free models that meet accepted energy usage and environmental criteria. The retailer is responsible for making sure that the old appliance is properly disposed: either reused or recycled by a certified recycling company. The program was successful in meeting its goal: e.g., shifting the market share of green refrigerators and freezers from $20 \%$ to $40 \%$ in the first four months of the program (Sept. 1, 1993 to Dec. 31, 1993). The average difference in energy consumption between "green" and "non-green" models was found to be $110 \mathrm{kWh} /$ year.

\section{Spain: Efficient Air Conditioning Program}

From 1988-90, a Spanish utility implemented an air conditioning program in the residential and commercial new construction sectors. Rebates were offered to customers to install high-efficiency air conditioners, and the utility promoted the program through newspaper, radio, and television advertising, as well as through brochures, direct mail, shows and exhibits. As noted below, as intended, the program led to increased energy use due to increased air-conditioner ownership.

\section{Spain: Night Tariff Program}

From 1989-91, a Spanish utility implemented a night tariff program in the residential and commercial sectors by offering rebates to customers to use more electricity at night. In addition to publicizing the program through newspaper, radio, and television advertising, the utility promoted the program through brochures, direct mail, shows and exhibits.

\section{Sweden: Market Transformation of High-Frequency Ballasts}

Since April 1990, NUTEK has been trying to influence the market of high-frequency ballasts in the commercial and industrial sectors (in both existing and new buildings), by using technology procurement, bulk purchasing, rebates, and services, and by working with electrical contractors, consultants, and purchasers (Göransson and Faugert 1994).

\section{DSM PROGRAM COMPARISONS}

Comparing the cost and performance of DSM programs from different countries and organizations is a difficult and daunting task, since utilities and governments have different DSM and program objectives, budgets, experience and expertise in DSM program implementation and evaluation, etc. The experience of the first year of the INDEEP project demonstrated that it is possible to collect DSM program data consistently using a standardized data collection instrument. However, not all fields of interest (e.g., 
participation rates and participant costs) could be collected for all programs. Moreover, the analysis of measured consumption data with a comparison group was limited (see below). Finally, the amount of effort required to collect these kinds of data was extensive, so that a shorter data collection instrument will be used in the second year of the project to collect similar types of information (Vine 1995).

All but one of the DSM programs examined in this paper were implemented by a utility company (Table 2). The types of DSM programs evaluated are quite varied, covering efficient appliances, fuel switching, load management (including time-of-use pricing), and market transformation. Over half of the programs continue to operate, while the rest were terminated after only 1-2 years of operation (as designed, in some cases). This short program duration is not sufficient for program maturity, significantly penetrating the market, and capturing large energy savings (see also Mills 1993).

Most of the programs tried to encourage the installation of energy efficiency measures through subsidies, while other programs relied on general information or site-specific audits to convince consumers to install such measures. And in two of Austria's programs, operations and maintenance were an important part of the energy efficiency program.

In addition to saving energy, utilities promoted these programs for other reasons: e.g., business development, environmental quality, load management, public image, and quality of service. And in a few cases, fuel switching, comfort and the quality of life, and long-term resource benefits were also considered important. Clearly, the more efficient use of resources by itself was rarely the only reason. for promoting DSM. In a more competitive environment being implemented or considered in a number of countries and by the Commission of the European Union, non-energy reasons may become even more important for promoting DSM.

The marketing methods used in these programs included brochures, direct mail, direct contacts, advertising (radio, television, and newspaper), shows and exhibits, seminars and workshops, and tests and demonstrations. In one program, telemarketing was used, a technique that is rarely used elsewhere. Unfortunately, due to the small size of the sample, we were unable to measure the effectiveness of these varied methods. 
Table 2. Overview of European DSM Case Studies

\begin{tabular}{|c|c|c|c|c|c|c|c|}
\hline Country & Program ID\# & \begin{tabular}{|c} 
Primary \\
Implementing \\
Agent (1)
\end{tabular} & Program Name & $\begin{array}{l}\text { Program } \\
\text { Lifetime } \\
\end{array}$ & $\begin{array}{c}\text { Program } \\
\text { Type (2) } \\
\end{array}$ & $\begin{array}{c}\text { Motivations } \\
(3)\end{array}$ & $\begin{array}{c}\text { Marketing } \\
\text { Methods } \\
\text { (4) }\end{array}$ \\
\hline Austria & A-1 & U & $\begin{array}{l}\text { District Heating and Fuel } \\
\text { Switching }\end{array}$ & 1992-ongoing & $\mathrm{A}, \mathrm{M}, \mathrm{O} \& \mathrm{M}$ & $\begin{array}{l}\mathrm{BD}, \mathrm{EE}, \mathrm{EQ}, \\
\text { FS, } \mathrm{PI}, \mathrm{QS}\end{array}$ & $B, D C U, S W$ \\
\hline Austria & $\mathrm{A}-3$ & $\overline{\mathrm{U}}$ & Heat Pump & 1980- ongoing & $\mathrm{A}, \mathrm{M}, \mathrm{O \& M}$ & $\begin{array}{l}\text { EE, EQ, FS, } \\
\text { LT, PI }\end{array}$ & $\begin{array}{l}\text { DCT, DCU, N, NA, } \\
\text { SE, SW, TD }\end{array}$ \\
\hline Austria & A-4 & $\bar{U}$ & Commercial Load Management & 1992-1994 & $\overline{I, L C, M}$ & $\begin{array}{l}\text { EE, LM, PI, } \\
\text { QS }\end{array}$ & $\overline{D C U}, \mathrm{SW}$ \\
\hline Denmark & $\mathrm{D}-2$ & $\mathrm{U}$ & Industrial Audit & 1987-ongoing & $\mathrm{A}$ & $\mathrm{BD}, \mathrm{EE}$ & $\overline{\mathrm{DM}}$ \\
\hline Denmark & $\mathrm{D}-3$ & $\mathrm{U}$ & Trade and Public Sector Audit & 1987-ongoing & $\mathrm{A}$ & $\overline{\mathrm{BD}}, \mathrm{EE}$ & $\overline{\mathrm{DM}}$ \\
\hline Denmark & $\mathrm{D}-4$ & $\bar{U}$ & Residential Lighting & $\begin{array}{l}\text { 1993-ongoing } \\
\end{array}$ & T & $\mathrm{EE}$ & B, NA. RA. TD \\
\hline Netherlands & $\mathrm{N}-1$ & $\mathrm{N \& U}$ & Compact Fluorescent Lamp & 1993-1994 & $\mathrm{M}$ & $\mathrm{EE}, \mathrm{EQ}$ & GA, NA.RA.SE \\
\hline Netherlands & $\mathrm{N}-2$ & N\&U & $\begin{array}{l}\text { Energy-Efficient Refrigerator and } \\
\text { Freezer }\end{array}$ & 1993-1994 & $\bar{M}$ & $\begin{array}{l}\text { EE, EQ, LM, } \\
\text { PI }\end{array}$ & $\overline{B, N}$ \\
\hline Spain & SP-1 & $\bar{U}$ & Efficient Air Conditioning & $1988-1990$ & $\mathrm{I}, \mathrm{M}$ & EE, LM, QS & $\begin{array}{l}\text { B, DCT,DCU, DM, } \\
\text { GA, NA, RA, SE }\end{array}$ \\
\hline Spain & SP-2 & $\overline{\mathrm{U}}$ & Night Tariff & 1989-1991 & I, LC & $\begin{array}{l}\text { EE, LG, LM, } \\
\mathrm{QS}\end{array}$ & $\begin{array}{l}\text { B,DCT, DCU, DM, } \\
\text { GA, N, NA, RA, SE, } \\
\text { SW, T, TD }\end{array}$ \\
\hline
\end{tabular}

Notes:

(1) Primary implementing agent: $G=$ Government; $N=$ National organization of energy distributors; $U=U$ Utility

(2) Program type: A = Audits; I = Information; LC = Load control; $M=$ Installation of energy-efficiency measures; $O \& M=$ Operations and maintenance

(3) Motivations: $\mathrm{BD}=$ Business development; $\mathrm{EE}=$ Energy efficiency; $\mathrm{EQ}=$ Environmental quality; $\mathrm{FS}=$ Fuel switching; IC = Increase comfort and quality of life; $\mathrm{LG}=\mathrm{Legislated}$ / mandated; $\mathrm{LL}=$ Lighting level and quality improvements; $\mathrm{LM}=\mathrm{Load}$ management; $\mathrm{LT}=\mathrm{Long}$-term resource benefits; $\mathrm{PI}=$ Public image; $\mathrm{PR}=$ Price reduction of equipment; $\mathrm{QS}=\mathrm{Quality}$ service

(4) Marketing methods: $\mathrm{B}=$ Brochures; $\mathrm{BI}=$ Bill inserts; $\mathrm{DCT}$ - Direct contact by trade ally; $\mathrm{DCU}=$ Direct contact by utility; $\mathrm{DM}=\mathrm{Direct}$ mail; $\mathrm{GA}=$ General advertising; $\mathrm{N}=$ Newsletters; NA = Newspaper advertising; $\mathrm{RA}=\mathrm{Radio} / \mathrm{TV}$ advertising; $\mathrm{SE}=\mathrm{Shows} / \mathrm{exhibits;} \mathrm{SW}$ $=$ Seminars $/$ workshops; $\mathrm{T}=$ Telemarketing; $\mathrm{TD}=$ Tests/demonstrations 
Cumulative participation rates in the DSM programs in this sample ranged from less than $1 \%$ to $63 \%$ (Table 3). On average, these programs have higher penetration rates than those in the United States, which are typically less than $15 \%$ (with many in the $5-10 \%$ range). The relatively higher degree of success in particiption may reflect the extensive amount of marketing of the programs. Because of the size and heterogeneity of the sample, we were unable to determine the primary reasons leading to successful program participation.

As with program participation, the cost-effectiveness of these programs varied significantly (Table 3). From the utility perspective, the average levelized utility resource cost (excluding the Spanish programs that led to increased energy use) was $0.016 \mathrm{ECU} / \mathrm{kWh}(2.0 \mathrm{\&} / \mathrm{kWh})$, and from a total resource cost perspective (when participant costs are added to utility costs), the average cost $(0.027 \mathrm{ECU} / \mathrm{kWh}$ $(3.3 \mathrm{k} / \mathrm{kWh}$ ) was close to the measured performance of some DSM programs in the United States (e.g., $3.9 \mathrm{k} / \mathrm{kWh}$ for a sample of 20 commercial lighting programs - Eto et al. 1994). ${ }^{7}$ And when weighted by energy savings, the average cost of energy saved by the programs was $0.014 \mathrm{ECUs} / \mathrm{kWh}(1.8 థ / \mathrm{kWh})$. In some cases, the programs were very cost effective, compared to the avoided cost of new supply (e.g., 2.2 $4 / \mathrm{kWh}$ in the case of the Netherlands (Koster 1995). However, in other cases, the situation was different: e.g., Austrian's electric appliance exchange program (A-2) was twice as expensive as generating costs due to the high costs of the program (including participant costs). As noted previously, the size and heterogeneity of the sample prevented us to determine the primary reasons affecting program performance.

The actual performance of these programs is uncertain due to the utilities' limited experience in evaluating DSM (especially, energy efficiency) programs (Table 4). Many of the programs relied on engineering data and engineering analysis for estimating energy savings, while billing data were used in only a few cases to statistically analyze changes in consumption. And in a few cases, program costs were unavailable (see Table 3). In addition to the uncertainty of program results, several of these programs had broad objectives in trying to transform the market of energy efficiency goods and services through information and audit programs, as well as market-pull programs. Consequently, while the cost-effectiveness of DSM programs is important from a resource perspective, other measures of program performance need to be taken into account, such as the degree to which the energy-efficiency market has been transformed (e.g., greater availability of efficient equipment), as demonstrated in the Swedish DSM case study. 
Table 3. Cost and performance of European DSM programs (1)

\begin{tabular}{|c|c|c|c|c|c|c|c|c|c|c|}
\hline $\begin{array}{c}\text { Program } \\
\text { ID\# } \\
\text { (2) }\end{array}$ & $\begin{array}{c}\text { Number of } \\
\text { Participants } \\
\text { (Cumulative) (3) }\end{array}$ & $\begin{array}{c}\begin{array}{c}\text { Participation } \\
\text { Rate } \\
(\%)\end{array} \\
\end{array}$ & $\begin{array}{c}\text { Utility Costs } \\
\text { (in 1,000 } \\
\text { ECUs) }\end{array}$ & $\begin{array}{c}\text { Participant } \\
\text { Costs } \\
\text { (in } 1,000 \\
\text { ECUs) } \\
\end{array}$ & $\begin{array}{c}\text { Total } \\
\text { Program } \\
\text { Costs (in } \\
1,000 \text { ECUs) } \\
\end{array}$ & $\begin{array}{c}\text { Gross } \\
\text { Energy } \\
\text { Savings } \\
\text { (MWh) } \\
\end{array}$ & \multicolumn{2}{|c|}{$\begin{array}{l}\text { Levelized Total } \\
\text { Resource Cost (4) }\end{array}$} & \multicolumn{2}{|c|}{$\begin{array}{l}\text { Levelized Utility } \\
\text { Resource Cost (4) }\end{array}$} \\
\hline$A-1$ & $730 \mathrm{hh}$ & 2 & NA & $\mathrm{NA}$ & $\mathrm{NA}$ & 5,400 & NA & {$[\mathrm{NA}]$} & NA & [NA] \\
\hline $\mathrm{A}-2$ & $24,402 \mathrm{hh}$ & 15 & 4,440 & 11,000 & 15,440 & 18,450 & 0.077 & 9.7 & 0.022 & 2.8 \\
\hline$A-3$ & $13,500 \mathrm{hh}$ & NA & $\mathrm{NA}$ & NA & NA & NA & NA & INA & NA & INA \\
\hline$A-4$ & $6 \mathrm{cc}(5)$ & $<1$ & 17,780 & 5,330 & 23,110 & 43,200 & 0.058 & 77.2 & 0.045 & 5.6 \\
\hline $\mathrm{D}-1$ & $60,000 \mathrm{hh}$ & 30 & 1,006 & 357 & 1,363 & 11,400 & 0.012 & 1.5 & 0.009 & 1.1 \\
\hline $\mathrm{D}-2$ & $1,700 \mathrm{ic}$ & 30 & 2,350 & 900 & 3,250 & 128,000 & 0.006 & 0.8 & 0.005 & 0.6 \\
\hline $\mathrm{D}-3$ & $3,700 \mathrm{ic}$ & 30 & 1,200 & 1,000 & 2,200 & 60,000 & 0.008 & 1.0 & 0.004 & 0.5 \\
\hline $\mathrm{D}-4$ & $500,00 \mathrm{hh}$ & 50 & $\frac{1,100}{1,100}$ & 7,700 & 8,800 & 135,700 & 0.011 & $\mid 1.3$ & 0.001 & 0.2 \\
\hline$\overline{N-1}$ & $4,391,000 \mathrm{hh}$ & 30 & 160 & 100 & 260 & 80,000 & 0.0005 & {$[0.01]$} & 0.0003 & 10.04 \\
\hline $\mathrm{N}-2$ & NA & 25 & 313 & 100 & 413 & $\frac{1,200}{20}$ & 0.032 & 4.8 & 0.024 & 3.0 \\
\hline SP-1 & $150,000 \mathrm{hh}$ & 28 & 505 & 27,000 & 27,505 & {$[110,000](6)$} & 0.012 & $\mid 1.4$ & 0.0002 & 0.03 \\
\hline SP-2 & $54,736 \mathrm{hh}$ & 63 & 3,199 & 32,500 & 35,699 & $1110,000(6)$ & 0.015 & 1.9 & 0.001 & 0.2 \\
\hline SW-1 & $\mathrm{NA}$ & (7) & 1,758 & NA (8) & 1,758 & $4,760(9)$ & 0.034 & 4.3 & 0.034 & 4.3 \\
\hline Whichto & $1=0$ & & & & & & 00014 & 178 & 0004 & T5 5 \\
\hline$\frac{\text { Welghted }}{\text { Average ( }}$ & $\begin{array}{l}\text { Average (10) } \\
\text { 0) }\end{array}$ & & & & & & $\frac{0.014}{0.027}$ & $\frac{1.0}{3.3}$ & $\frac{0.004}{0.016}$ & $\frac{0.3}{2.0}$ \\
\hline Standard & eviation & & & & & & 0.026 & 3.3 & 0.016 & 2.0 \\
\hline
\end{tabular}

NA $=$ Not Available

(1) Participation, data are cumulative, but cost, and energy savings data are annual.

(2) See Table 2 for identification of program ID numbers.

(3) Participants: $\mathrm{cc}=$ commercial customers; $\mathrm{h}$ h $=$ households; ic $=$ industrial customers.

(4) For calculating the levelized total resource cost, we calculate the total resource cost for each program (utility and participant costs) by using the discount rate ( $5 \%$ real) to levelize total costs over the average economic lifetime of installed measures for each program. The levelized costs are then divided by annual energy savings. For our calculations: $\$ 1=0.80 \mathrm{ECUs}$, or $1 \mathrm{ECU}=\$ 1.20$, and all dollars have been adjusted to 1994 dollars. The levelized utility resource cost was calculated in the same manner, except participant costs were excluded from the calculation.

(5) For pilot program only.

(6) This program resulted in increased energy use, due to increased saturation of air conditioners (SP-1) or increased off-peak electricity use (SP-2).

(7) Market share penetration of high-frequency ballasts: 1-2\% (1990), 5\% (1991), 16\% (1992), and 20-25\% (1993).

(8) Participant costs have not been tracked, but are assumed to be zero for calculating the levelized total resource cost.

(9) This is the savings for one year, and excludes savings for future years even though program costs are negligible.

(10) Averages exclude Spanish DSM programs, since they led to increased energy use in valley periods. The weighted average is the average of the programs weighted by energy savings. 
Table 4. Impact evaluation data, methodologies, and samples

\begin{tabular}{|l|l|l|l|}
\hline $\begin{array}{c}\text { Program } \\
\text { ID\# (1) }\end{array}$ & Impact Evaluation Data Sources & Impact Evaluation Methodologies & Group(s) Analyzed \\
\hline \hline A-1 & Site specific data & Statistical and engineering analysis & Participants \\
\hline A-2 & Utility billing data & Statistical analysis & Participants and comparison group \\
\hline A-3 & Engineering data & Engineering analysis & Participants \\
\hline A-4 & $\begin{array}{l}\text { Utility billing and whole-building } \\
\text { load data }\end{array}$ & Statistical and engineering analysis & Participants \\
\hline D-1 & Equipment specifications & Engineering analysis & Participants and comparison group \\
\hline D-2 & Engineering and site specific data & Engineering analysis & Participants \\
\hline D-3 & Engineering and site specific data & Engineering analysis & Participants \\
\hline D-4 & Engineering data & Engineering analysis & Participants \\
\hline N-1 & $\begin{array}{l}\text { Engineering, utility billing, spot } \\
\text { metering, data and data from other } \\
\text { sources }\end{array}$ & Statistical and engineering analysis & Participants \\
\hline N-2 & Engineeringdata & Participants and comparison group \\
\hline SP-1 & $\begin{array}{l}\text { Engineering data and data from other } \\
\text { sources }\end{array}$ & Engineering analysis & Engineering analysis \\
\hline SP-2 & $\begin{array}{l}\text { Engineering data and data from other } \\
\text { sources }\end{array}$ & Engineering analysis & Participants \\
\hline SW-1 & $\begin{array}{l}\text { Engineering data, spot metering, } \\
\text { equipment specifications, site specific } \\
\text { data, and interview data }\end{array}$ & Engineering analysis & Participants and nonparticipants \\
\hline & & & \\
\hline
\end{tabular}

Note:

(1) See Table 2 for identification of program ID numbers. 


\section{LESSONS LEARNED AND TRANSFER OF PROGRAM EXPERIENCE}

During the data collection process, program managers and evaluators of these 13 DSM programs were asked to assess the performance of their program and to describe some of the lessons learned during the design, implementation, and evaluation of these programs. Based on this sample, the following lessons were learned: (1) utilities consider non-energy reasons (e.g., environmental quality and public image) to be important when selecting and implementing DSM programs; (2) consumers also consider non-energy reasons (e.g., environmental quality and indoor comfort) to be important in deciding to participate in DSM programs; (3) pilot programs are useful for assessing the needs of customers, so that full-scale programs can address their needs; and (4) mass-media advertising can be effective in attracting program participants.

In addition to utility commitment, the success of a DSM program is thought to be systematically related to aspects of program design and implementation. However, a precise understanding of how program success is related to specific program features is severely limited by: (1) the small size and heterogeneity of the sample, (2) short program lifetimes, and (3) inadequate evaluation data and analytical methodologies. To better understand the key factors affecting program success, a larger data set for analysis and better post-program information is needed.

Because of the limited number of case studies, it is premature to provide a comprehensive and definitive assessment of whether the results and experiences of DSM programs can be transferred from one utility to another and from one country to another. However, the preparation of the DSM case studies and the participants" experience in working withthe INDEEP data collection instrument indicate that the DSM program results and experience can be transferred from one location to another, if at least two provisions are fulfilled: (1) the data need to be collected consistently using a standardized data collection instrument that includes a set of instructions (definitions); and (2) the information on the cost and performance of DSM programs must be placed in a broader context of the utility and customer environments in each country (e.g., energy prices and rates, market barriers, regulatory incentives and disincentives, motivations for pursuing DSM, the market for energy efficiency, and the extent of privatization and regulation of the power industry). We expect that energy efficiency measures and program delivery systems can be transferred from one country to another, or one region to another. Similarly, program evaluation processes and methodologies can also be transferred; however, differences in nomenclature, the level of integration of evaluation in program design and implementation, and the amount of expertise and resources in an organization may limit the amount and type of information that can be transferred (Bowie 1993). But these short-term barriers may be overcome in the near future as evaluation assumes a more important role. 


\section{THE FUTURE}

As noted at the beginning of this paper, the current level of utility energy efficiency programs (in contrast to load management programs) in most European countries is low compared to the United States, and the future of energy efficiency is uncertain given potential structural changes in the utility industry. As the market changes from a protected, monopolistic situation to a competitive environment, utilities will need to re-examine and re-assess the roles of integrated resources planning, demand-side management, and energy efficiency. On the other hand, energy efficiency programs promoted by government may increase: many European countries have made commitments to the United Nations Framework Convention on Climate Change for reducing or stabilizing their $\mathrm{CO}_{2}$ emissions, and, therefore, energy efficiency is expected to play a pivotal role in this environmental agenda (OECD/IEA 1994). For example, energy efficiency measures that are additional to existing ones are expected to bring about a $3 \%$ reduction in $\mathrm{CO}_{2}$ emissions from average $1989 / 90$ levels by 2000 in the Netherlands $($ ibid). Thus, governmental energy efficiency programs will likely play an important role for environmental reasons.

Given a future of increased DSM activity (including both load management and energy efficiency), DSM program evaluation will also become more important, increasing the value of international collaborations such as the INDEEP project. Recognizing the value of program evaluation, the IEA is completing a report on program evaluation for government energy efficiency programs. Hopefully, these activities and country-specific efforts (e.g., Bowie 1993) will facilitate the documentation of the measured cost and performance of DSM programs, so that better program designs can be readily identified and adopted. And in a more competitive future, program evaluation will be critical for assessing utility profitability and customer services and for improving organizational efficiency and efficacy.

\section{ACKNOWLEDGMENTS}

This work was supported by the Assistance Secretary for Energy Efficiency and Renewable Energy, Office of Utility Technologies, of the U.S. Department of Energy under Contract No. DE-AC0376SF00098. The following organizations also supported this work: Energieverwertungsagentur (Austria), DEFU (Denmark), Commission of the European Union [Joint Research Center], RaCER (Korea), NOVEM (Netherlands), Red Electrica de España and UNESA (Spain), and NUTEK (Sweden). The author is especially grateful for the assistance and review comments provided by the following INDEEP project experts: Flavio Conti, Changseob Kim, Casper Kofod, Sibe Koster, Anders Lewald, Felix Martinez, Jan Möller, Mariana Ortiz, Waltraud Schmid, and Harry Vreuls. Special thanks are 
also due to the individuals who reviewed an earlier version of this paper: Joe Eto, Chuck Goldman, Reinhard Haas, Stale Johansen, Nathan Martin, Tim McIntosh, Alan Meier, Diane Pirkey, David Rubin, and Hans Westling.

\section{ENDNOTES}

1. In this paper, we refer to DSM as a set of customer-focused activities that are intended to affect the amount and timing of customer energy use cost-effectively. DSM programs include load management and energy efficiency (which may include fuel substitution) activities, along with an evaluation of results. DSM includes programs by utilities and government with a primary focus on energy efficiency. This definition is different than the one used in the United States in which the utility company is the principal organization promoting DSM.

2. The Commission of the European Union (EU) is also sponsoring this project, and EU-funded projects may eventually be included in INDEEP. Because the focus of this paper is on European DSM programs, this paper does not address the DSM experience in Korea, or the studies funded by the EU (see Endnote 4).

3. For example, at least 52 financial-incentive programs for compact fluorescent lamps were implemented in 11 European countries between 1987 and 1992 (Mills 1993).

4. The Commission of the European Union started the SAVE program in 1991 to re-establish energy efficiency as a priority for both the public and private sectors. In 1992, the Commission's first DSM pilot project was established under the SAVE program. Approximately 30 DSM/IRP projects are being implemented, although many of these are feasibility studies.

5. The Federal government, the Länder, and regional utilities maintain more than 70 energy efficiency and information centers in Austria.

6. ECUs are converted to 1994 U.S. dollars: $\$ 1=0.80 \mathrm{ECU}$, or $1 \mathrm{ECU}=\$ 1.20$.

7. For calculating the levelized total resource cost, we calculate the total resource cost for each program (utility and participant costs) by using the discount rate ( $5 \%$ real) to levelize total costs over the average economic lifetime of installed measures for each program. The levelized costs are then divided by annual energy savings. For our calculations: $\$ 1=0.80 \mathrm{ECUs}$, or $1 \mathrm{ECU}=\$ 1.20$, and all dollars have been adjusted to 1994 dollars. The levelized utility resource cost was calculated in the same manner, except participant costs were excluded from the calculation. 


\section{REFERENCES}

Bowie. R. 1993. “Are Demand-Side Management Activities Effective? A Program to Provide a Swedish Tradition of Evaluation. A Swedish Handbook for the Evaluation of DSM Activities." Proceedings from the Second International Energy Efficiency and DSM Conference: Customer Focus. Synergistic Resources Corporation, Bala Cynwyd, PA.

CIGRE. 1994. "Relationship Between Power System Planning and Factors Affecting the Electricity Demand: IRP/LCP/DSM." Report No. 37.94(WG11)08(E). International Conference on Large High Voltage Electric Systems.

Eto, J., E. Vine, L. Shown, R. Sonnenblick, and C. Payne. 1994. "The Cost and Performance of Utility Commercial Lighting Programs." LBL Report 34967. Lawrence Berkeley Laboratory, Berkeley, CA.

Göransson, C. and S. Faugert. 1994. "Effective Market Influence: An Effect Chain Analysis of NUTEK's High-Frequency Lighting Campaign." SIPU Utvärdering AB, Stockholm, Sweden.

Haas, R. 1995. "Some Empirical Findings of an Austrian Appliance Turn-in Program," Energy: The International Journal, forthcoming.

Hirst, E. and S. Hadley. 1994. "The DSM Sky Hasn't Fallen Yet." The Electricity Journal 7(10): 77-79.

Koster, S. 1994. Personal communication from Sibe Koster, NOVEM, January 10.

Mills, E. 1993. "Efficient Lighting Programs in Europe: Cost Effectiveness, Consumer Response, and Market Dynamics." Energy: The International Journal 18(2):131-144.

NUTEK. 1993. "Purchasers' Requirements Dictate Development: A Study of Technology Procurement." The National Board for Industrial and Technical Development, Stockholm, Sweden.

Organisation for Economic Co-Operation and Development (OECD), and International Energy Agency (IEA). 1994. "Climate Change Policy Initiatives, 1994 Update. Volume 11, OECD Countries." Organisation for Economic Co-Operation and Development, Paris, France.

Schmid, W. 1993. Personal communication from Waltraud Schmid, Energie Verwertungsagentur, October 27.

UNIPEDE. 1994. "Integrated Resource Planning and Demand Side Management in Europe: Present Status and Potential Role." Economics and Tariffs Study Committee, 60.04 TAROPT. 
Vine, E. 1993. "Opportunities for International Cooperation: International Database on Energy Efficiency Programs (INDEEP)." Proceedings from the International Conference on Demand-Side Management, International Energy Agency, Paris, France.

Vine, E. 1995. “INDEEP Annual Report (1994-1995).” LBL Report 36876. Lawrence Berkeley Laboratory, Berkeley, CA.

Vine, E., C. Payne, and R. Weiner. 1993. "Comparing the Results of Energy Efficiency Programs: The Creation of a National Data Base on Energy Efficiency Programs (DEEP)." LBL Report 33655. Lawrence Berkeley Laboratory, Berkeley, CA. 